\section{Feilaktig om bløtdelsskader etter nakkesleng}

Det er forunderlig at anatomen Per Holck bruker en oversiktsartikkel om cervikalcolumnas anatomi til å spekulere omkring et organisk substrat for langtidsfølger etter nakkesleng (1). De fleste som har gjennomgått en trafikkulykke med nakkeslengsmekanisme, har kun vært utsatt for lavhastighetskollisjoner med belastninger på halsvirvelsøylen innenfor det man får ved dagligdagse aktiviteter. Holcks betraktninger blir av den grunn lite meningsfylt. Det er også vist at langtidssymptomer pga. nakkesleng praktisk talt ikke forekommer i land der det er minimale erstatningsmuligheter.

Gjennom de forskjelligste bildediagnostiske metoder har man lenge forgjeves forsøkt å finne kilden til de anførte symptomer. Tyskerne Volle og Montazem mente $\mathrm{i}$ en liten, ukontrollert MR-studie i 2001 å ha funnet skader i alarligamentene. Sveitsiske forskere kunne imidlertid vise at et liknende signalmønster ikke var uvanlig hos helt friske individer. Upåaktet av dette mente nevroradiologen Kråkenes og fysioterapeuten Kaale at de med forbedret MRteknikk kunne demonstrere ligamentlesjoner (2). Nær halvparten av de undersøkte nakkeslengsutsatte hadde alarligamentsignaler som ble tolket som en tydelig skade. Hos ingen av de 30 uskadede kontrollpersonene fant man liknende forandringer. Resultatene ble møtt med stor tvil. I en forbedret MR-studie med to kontrollgrupper kunne Myran og medarbeidere vise at de påståtte skadetegn forekommer med sammenliknbar hyppighet hos uskadede kontrollpersoner (3).

Den endelige sluttstrek for at det kan finnes en påviselig organisk skade i nakken etter vanlig nakkesleng setter nå en MRstudie fra Oslo. Nevroradiologen Dullerud og medarbeidere fant at gjennomsnittlig $50 \%$ av dem med nakkesleng og $50 \%$ av kontrollpersonene hadde høy signalintensitet av alar- og transversalligamentene (4).

Motivet for vinklingen av Holcks artikkel er uklart. Han oppgir ingen interessekonflikter. Vi går derfor ut fra at han ikke planlegger å opptre som sakkyndig på erstatningssøkeres side i fremtidige nakkeslengssaker. Han hører som ikke-kliniker heller ikke hjemme der. Sakkyndige med klinisk relevant bakgrunn har tilstrekkelige anatomiske kunnskaper for å kunne gi retten de nødvendige opplysninger.

Vi frykter at det eneste man oppnår med en slik artikkel er gjennom noceboeffekten å skremme mennesker med nakkesleng ut i uførhet. Spekulative antakelser om strukturelle skader i nakken har dessverre ført til at man på tynt grunnlag har utført drastiske kirurgiske inngrep i nakken - med til dels katastrofale følger.

Til orientering: Undertegnede har ikke tatt oppdrag for forsikringsselskaper i nakkeslengssaker på mange år og har ingen planer om å gjøre det $\mathrm{i}$ fremtiden.

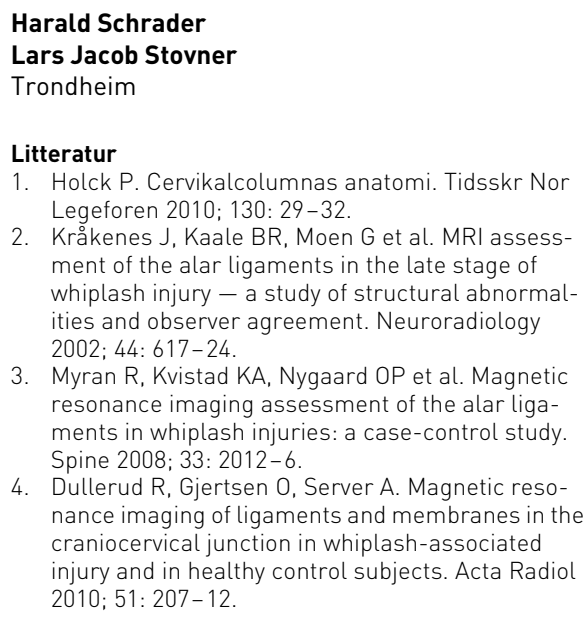
resonance imaging assessment of the alar ligaments in whiplash injuries: a case-control study. Spine 2008; 33: 2012-6.

4. Dullerud R, Gjertsen O, Server A. Magnetic resonance imaging of ligaments and membranes in the craniocervical junction in whiplash-associated injury and in healthy control subjects. Acta Radiol 2010; 51: 207-12.

\section{P. Holck svarer:}

Kollegene Schrader \& Stovner må ha lest min artikkel som en viss mann leser Bibelen. I artikkelen nevnes verken laveller høyhastighetskollisjoner, ei heller noen slags «anførte symptomer». Heller ikke forstår jeg at motivet for vinklingen av min artikkel kan betviles. Den er rett og slett en oversiktsartikkel som beskriver cervicalcolumnas anatomi, verken mer eller mindre.

Noe av poenget $i$ artikkelen var imidlertid å sette søkelyset på utspørringen ved registrering av nakkeslengsskader. Jeg er ikke overbevist om at dette skjer på en god måte, siden utspørringsteknikken sjelden er tilfredsstillende dokumentert. Dersom det kun spørres om aktuell skade, slik at pasienten utelukker eldre skader, for eksempel fra barndommen, er det ikke rart det blir en relativt stor andel av ligamenter med høy signalintensitet også hos «friske» individer.

Hvorfor skulle ikke en anatom kunne opptre som sakkyndig i en nakkeslengssak? Er det ikke i de fleste slike tilfeller snakk om en mekanisk skade på anatomiske strukturer, som vel en anatom må kjenne minst like godt - ja antakelig bedre - som en nevrolog som ikke har foretatt nakkedisseksjoner siden studietiden? En nevrologisk sykdom blir derimot noe helt annet. Det skulle ikke forundre meg om anatomen også har ganske god greie på de strukturer som ikke er umiddelbart tilgjengelige for nevrokirurgen.

Jeg beklager selvfølgelig at Schrader og Stovner ikke på mange år har tatt oppdrag for forsikringsselskaper, men jeg kan ikke se at dette ble nevnt eller var noe poeng i min oversiktsartikkel.

\section{Per Holck}

Institutt for medisinske basalfag

Avdeling for anatomi

Universitetet i Oslo 